\title{
Cukurova Medical Journal
}

\section{Araştırma Makalesi / Research Article}

\section{Comparative Study of Fibrin Sealent versus Use of Tackers in Inguinal Hernia Repair}

\author{
Kasık Fıtığı Onarımında Fibrin Dolgu Maddesi ve Zımba Tabancanın \\ Karşılaştırılması
}

\author{
Wasim Qadir Kar ${ }^{1}$, Mela Ram Atri ${ }^{1}$, Hanief Mohamed Dar ${ }^{1}$, Azher Mushtaq ${ }^{1}$, Sheikh Imran $^{1}$ \\ Ishfaq Ahmad Gilkar ${ }^{1}$. \\ ${ }^{1}$ Postgraduate department of surgery, GMC, Srinagar, Jammu \& Kashmir, INDIA.
}

Cukurova Medical Journal 2015;40(3):457-465.

\begin{abstract}
Purpose: To determine role and benefit of fibrin glue over tackers for mesh fixation in laparoscopic inguinal hernia repair.

Backgroud: Mesh fixation by tackers may lead to many complications peroperatively like bleeding, increased hospital stay and overall more cost and later on chronic groin pain.

Material and Methods: 60 inguinal hernia with age more than 18 years were taken and were divided in two groups; 30 patient group who underwent TAPP and 30 patient group who underwent TEPP. In 15 patients in both groups tackers were used and in other half fibrin glue was used for fixation of mesh using a $3 \mathrm{~mm}$ catheter (Duplotip: Baxter Healthcare), which fits the Tisseel syringe.

Results: The use of fibrin sealent has a distinct advantage in laparoscopic treatment of inguinal hernias compared with use of tackers as a method of mesh fixation. The use of fibrin sealant reduces the risk of post- and intraoperative complications, such as bleeding, seroma, chronic pain, has a lower incidence of postoperative neuralgia and provides an early faster return to social life. The recurrence rates do not vary much, but the operative time is slightly longer if the preparation time of the fibrin sealant is taken into consideration. In our study, we found a marginal difference in the cost of the two groups, fibrin sealant and stapled tackers.
\end{abstract}

Key words: laparoscopy; inguinal hernia; Fibrin sealent; tackers; Mesh fixation

\section{ÖZET}

Amaç: Laparoskopik kasık fıı̆ı̆ı onarımında yama fiksasyonunda kullanılan fibrin yapıştııcısının rolü ve yararının belirlenmesi.

Geçmiş: Tabancayla yapılan yama fiksasyonunda peroperatuar kanama gibi bazı komplikasyonların görülmesiyle kronik kasık ağrısı sonrasında hastanede kalma süresinin artışı genel olarak daha fazla maliyete neden olur.

Materyal ve Metod: 60 kasık fıtığı olan 18 yaş üzeri hastalar iki gruba ayrıldı bunlar; transabdominal preperitoneal onarımı geçiren 30 hasta ve total extraperitoneal onarımı geçiren 30 hasta. İki gruptaki 15 hastada tabanca kullanılırken geri kalan hastalarda fibrin yapıştııcı kullanıldı. Ağ fiksasyonu için 3mm katater ve buna uygun Tisseel şırınga kullanıldı (Duplotip: Baxter Sağlık Hizmet).

Bulgular: Laparoskopik tedavide kasık fıtı̆ı için kullanılan yama fiksasyon metodlarından tabanca ve fibrin dolgu materyalinin karşılaştırılması yapıldı. Fibrin dolgu materyalinin kullanımı, kanama, seroma, kronik ağı gibi post ve intraoperatif komplikasyon riskini azalttı. Postoperatif nevralji insidansı düşüktü ve hasta daha erken sosyal hayatına 
dönebilir. Nüks oranlarında çok farklılık yoktu. Ancak fibrin dolgu materyalinin hazırlık süresi dikkate alınırsa ameliyat süresi biraz daha uzundu. Çalışmamızda, fibrin dolgu materyali ve tabancayla zımbalanmış grupların maliyetinde marjinal bir fark bulundu.

Anahtar kelimeler: Laparoskopi, Kasık Fıtığı, Fibrin Dolgu Materyali, Zımba Tabanca, Ağ Fiksasyonu.

\section{INTRODUCTION}

Inguinal hernias are being repaired surgically by open as well as by laparoscopic means. Open repairs are tissue repairs and repairs using prosthesis. Laparoscopic groin hernia repair include intraperitoneal onlay mesh (IPOM), transperitoneal-abdominal approach (TAPP) and Total extraperitoneal approach (TEP) ${ }^{1}$. All the techniques use a prosthetic material, which is being secured by either using a conventional suture, or with staples or tacks, in particular. Despite the "tension-free" nature of these hernioplasties, sutures may cause strangulation of muscle fibres, or compression of the regional nerves, leading to invalidating pain or dysesthesia $^{2}$. One of the most frequent complications which present after inguinal hernia surgery is postoperative pain which, at times, is chronic and permanent and leads to poor quality of life ${ }^{3}$.

The incidence of these chronic complications was underestimated for a long time and is currently estimated to be between $0 \%$ and $75.5 \%{ }^{4}$. With the reduction or even disappearance of recurrences, this morbidity is now of importance, and therefore, Pooblan A.S et al modified the method used to anchor prosthesis using fibrin glue ${ }^{4}$. Fibrin glue/sealant is a commercial tissue adhesive containing fibrinogen and thrombin. The commercial product is a two component system from human plasma that contains more fibrinogen and thrombin. The first component contains highly concentrated fibrinogen, factor XIII, fibronectin, and traces of other plasma proteins. The second component contains thrombin, calcium chloride, and antifibrinolytic agent such as aprotinin. Mixing of two components leads to activation of fibrinogen and thrombin by calcium chloride, formation and cross linking of fibrin leading to the formation of polymerized fibrin chains, duplicating the last step of the coagulation cascade that is how it adheres the mesh to the tissues. The fibrinogen component gives tensile strength, thrombin stimulates fibroblast proliferation and aprotinin, an antifibrinolytic agent enhances the life span of the sealant.

Promising initial experimental results have shown that the strength of mesh fixation with fibrin glue is at least comparable to that using staples ${ }^{5}$. Increased fibroblast activity even resulted in better and faster incorporation of the mesh material ${ }^{6}$. A lower rate of early postoperative pain with earlier reconvalescence is reported, but also, and primarily, a reduction in chronic pain in comparison with mesh fixation using staples ${ }^{7}$. A significant decrease in seroma formation is described in most studies $^{8}$.

The main aim of our study was to compare mesh fixation using tacks verses mesh fixation using fibrin glue in terms of, Operative time, Complications (Intraoperative, Postoperative (immediate), Long term (>3 months), Length of hospital stay, Recurrence rate and Cost effectiveness.

\section{MATERIAL and METHODS}

This prospective, comparative study comprised of patients admitted for elective laparoscopic surgery for inguinal hernia in various surgical wards of SMHS Hospital, Srinagar, India. Patients were randomly picked for either of the two procedures. Randomization was done using computer based programme. The patients with unilateral or bilateral inguinal hernia and failed previous open hernia surgery/recurrent hernia were selected unbiased from either sex above 18 years of age and were evaluated as per history, examination, routine investigation and USG abdomen and pelvis. Patients with $\mathrm{BMl}>35$, 
connective tissue disorder, contraindication to laparoscopy, lower abdominal previous surgical scar except for open hernia repair and age $<18$ yrs were excluded from study.

\section{OPERATIVE TECHNIQUE}

\section{Mesh Fixation Using Fibrin Glue and Tackersin TAPP}

After proper evaluation, preanaesthetic checkup and consent for procedure, surgery was performed under general anesthesia. After creating pneumoperitonium two working ports were created and peritoneal cavity thoroughly evaluated with 30 degree camera. Hernia defect was located and peritoneal flaps elevated 1-2 cms above hernia orifice from anterior superior iliac supine up to pubic symphysis. Space for mesh placement was created by blunt dissection by lifting peritoneal flaps, peritalization of cord and dissection of cooper ligament. Mesh was then positioned so as to cover all hernia foramina, coopers ligament, triangle of pain, triangle of doom, epigastric vessels and spermatic cord. Mesh was secured to Cooper's ligament medially using a spiral tacker and then along its superior edge, above the iliopubic tract, with great care taken to avoid fixation near the inferior epigastric vessels. The mesh was manipulated to lay flat within the preperitoneal space. The peritoneal edge was then grasped and returned to its normal anatomic position, while the mesh was stabilized.

\section{Fixation of the Prosthesis Using Fibrin Glue}

In this technique mesh is fixed with $1 \mathrm{ml}$ of Tissucol for unilateral hernias and $2 \mathrm{ml}$ for bilateral hernias. The prosthesis is fixed along its upper margin, from Cooper's ligament to the "triangle of doom", and to the "triangle of pain" using a $3 \mathrm{~mm}$ catheter (Duplotip:Baxter Healthcare), which fits the Tisseel syringe. The mesh may also be fixed wherever necessary to increase its stability. Tisseel may be applied in two different ways: By resting the tip of the Duplotip catheter, where the mesh is to be fixed and by squeezing out a few drops of glue or the glue seeps across the mesh and fixes it. One can also separate the mesh slightly from the inguinal wall, spray the glue directly on it, and then place the mesh to the wall. Peritoneum is closed by intracoporal suturing or use of tacks or application of glue.

\section{Mesh Fixation Using Fibrin Glue and Tackers in TEP}

A curvilinear incision is made near the umbilicus and carried down to the anterior rectus sheath, which is incised, entering the rectus sheath. The rectus muscles are retracted laterally exposing the posterior rectus sheath. A peritoneal dissection balloon trocar is inserted and guided by manual and videoscopic guidance down to the level of the pubis where it was inflated and left as such for several minutes for temponade effect. It is then deflated, removed and replaced with a structural balloon trocar. Carbon dioxide insufflation is done and under direct vision two $5 \mathrm{~mm}$ trocars are placed in the middle hypogastrium, one suprapubically and the second midway between pubis and umbilicus. Cooper's ligament is identified along with cord structures and inferior epigastric vessels. The cord structures are skeletonized, and the hernia sac is reduced off the internal ring down to the level of peritoneum. The mesh is placed through the preperitoneum, unfolded and placed uncut over the myopectinate orifice.The two solutions of the fibrin sealant are drawn into separate syringes, which are then fitted into the laparoscopic applicator. Once the mesh is deployed in the desired position, it is secured to the pubic bone (Cooper's ligament) in the midline, the lacunar ligament laterally, and superiorly into the transversalis fascia with the fibrin sealant, which is allowed to set for several minutes, or the mesh can be secured using spiral tacks. The posterior aspect of the matrix repair is held in place as the pneumopreperitonium is released under direct vision, observing the peritoneum to obtain its desired position relative to matrix repair 


\section{Postoperative Care}

After the operation patients were shifted to the ward and monitored. For the immediate postoperative pain relief, injectable diclofenac sodium $75 \mathrm{mg}$ was used, later oral diclofenac sodium $75 \mathrm{mg}$ was used. Patients were made ambulatory, and orals were started in the evening on the same day of operation in both the techniques. Patients were discharged from the hospital as soon as the patient became ambulatory and tolerated orals. Patients were then called for follow-up at 1 week, 2 weeks, 4 weeks, 3months and 6 months.

Parameters recorded were, operative time, intraoperative and postoperative complications, duration of hospitalization, cost of surgery and recurrence was evaluated by physical examination during regular follow ups.

\section{Statistical Analysis}

Data were expressed as average and percentage. All the inferences for intergroup comparison was made using unpaired students $t$ test, chi square test, and fisher exact test, A pvalue of $<0.05$ was considered as significant.

\section{OBSERVATION and RESULTS}

A total of 60 patients irrespective of demographic profile were taken into study. Minimum age was 19 years and maximum age was 78 years with mean age of $50.53 \pm 18.07$ years, while as in TAPP procedure using tackers, minimum age was 20 years and maximum age was 67 years with mean age of $52.2 \pm 13.88$ years. There were only two females in study, one in each groups.

In TAPP out of 30 patients fibrin sealent was used in 15 patients (14 males and 1 female) and tackers was used in 15 patients. In TEPP out of 30 patients fibrin sealent was used in 15 patients and tackers in 15 patients (14 males and 1 female). Most cases in both the methods had indirect inguinal hernia, $13(43.3 \%)$ in fibrin sealant group and $14(46.6 \%)$ in tacker group. Bilateral hernia was present in $6(20 \%)$ cases in fibrin sealant group, and $6(20 \%)$ cases in tacker group. Recurrent hernia was present in $4(13.3 \%)$ cases in fibrin sealant group, and $5(16.6 \%)$ cases in tacker group.

\section{Operative time}

Most common duration of intervention in TAPP and TEP procedures using fibrin sealant and tackers was (51-60 minutes). In TAPP procedure using fibrin sealant, minimum duration of intervention was 38 minutes and maximum duration of intervention was 84 minutes with mean duration of intervention of $59.60 \pm 11.28$ minutes, while as in TAPP procedure using tackers, minimum duration of intervention was 30 minutes and maximum duration of intervention was 74 minutes with mean duration of intervention of $51.06 \pm 11.60$ minutes, difference being statistically insignificant ( $P$ value $=0.0505$ ) (unpaired $t$ test).

In TEP procedure using fibrin sealant, minimum duration of intervention was 46 minutes and maximum duration of intervention was 90 minutes with mean duration of intervention of $65.73 \pm 12.76$ minutes, while as in TEP procedure using tackers, minimum duration of intervention was 40 minutes and maximum duration of intervention was 85 minutes with mean duration of intervention of $58.80 \pm 12.83$ minutes, difference being statistically insignificant $(P$ value $=0.1494)$ (unpaired $t$ test).

\section{Complications}

Our study observed higher incidence of complications among the tacker group than the fibrin sealant group.

In TAPP procedure using fibrin sealant, no intraoperative complication was noted. Only postoperative complications noted were one case of wound infection (6.6\%) and 2 cases of seroma (13.3\%).While as in TAPP procedure using tackers, no intraoperative complication was noted; only postoperative complications noted were one 
case each of scrotal swelling(6.6\%),seroma $(6.6 \%)$, and hematoma (6.6\%).

Chronic groin pain was noted in no patient $(0.0 \%)$ in fibrin sealant group and in 7 patients (46.6\%) in tacker group $(P=0.0279)$ (Table 1$)$.

In TEP procedure using fibrin sealant, no intraoperative complication was noted. Only postoperative complications noted were one case of hematoma $(6.6 \%)$ and one case of seroma
(6.6\%).While as in TEP procedure using tacker, no intraoperative complication was noted; only postoperative complications noted were one case of scrotal swelling (6.6\%) and one case of wound infection (6.6\%).

Chronic groin pain was noted in no patient $(0.0 \%)$ in fibrin sealant group and in 6 patients $(40.0 \%)$ in tacker group $(P=0.0304)$ (Table 2$)$.

Table 1. Complications in TAPP procedure

\begin{tabular}{|c|c|c|c|}
\hline $\begin{array}{l}\text { Intraoperative and postoperative } \\
\text { complications }\end{array}$ & $\begin{array}{c}\text { FIBRIN SEALANT } \\
(\% \text { age }) \\
\end{array}$ & $\begin{array}{r}\text { TACKERS } \\
\text { (\%age) } \\
\end{array}$ & $P$ value \\
\hline Vascular Injuries & $0(0.0 \%)$ & $0(0.0 \%)$ & n.a \\
\hline Bleeding & $0(0.0 \%)$ & $0(0.0 \%)$ & n.a \\
\hline Scrotal Swelling & $0(0.0 \%)$ & $1(6.6 \%)$ & 1.000 \\
\hline Visceral Injuries & $0(0.0 \%)$ & $0(0.0 \%)$ & n.a \\
\hline Wound Infection & $1(6.6 \%)$ & $0(0.0 \%)$ & 1.000 \\
\hline Seroma & $2(13.3 \%)$ & $1(6.6 \%)$ & 1.000 \\
\hline Hematoma & $0(0.0 \%)$ & $1(6.6 \%)$ & 1.000 \\
\hline Urinary Retention & $0(0.0 \%)$ & $0(0.0 \%)$ & n.a \\
\hline Inguinal Parasthesias & $0(0.0 \%)$ & $0(0.0 \%)$ & n.a \\
\hline Chronic groin pain & $0(0.0 \%)$ & $7(46.6 \%)$ & 0.0279 \\
\hline Total complications & 3.0 & 10.0 & \\
\hline
\end{tabular}


Table 2. Complications in TEP Procedure

\begin{tabular}{|l|l|l|l|}
\hline $\begin{array}{l}\text { Intraoperative and postoperative } \\
\text { complications }\end{array}$ & $\begin{array}{c}\text { FIBRIN SEALANT } \\
(\% a g e)\end{array}$ & $\begin{array}{l}\text { TACKERS } \\
(\% a g e)\end{array}$ & $0(0.0 \%)$ \\
\hline Vascular Injuries & $0(0.0 \%)$ & $0(0.0 \%)$ & n.a \\
\hline Bleeding & $0(0.0 \%)$ & $1(6.6 \%)$ & 1.000 \\
\hline Scrotal Swelling & $0(0.0 \%)$ & $0(0.0 \%)$ & n.a \\
\hline Visceral Injuries & $0(0.0 \%)$ & $1(6.6 \%)$ & 1.000 \\
\hline Wound Infection & $0(0.0 \%)$ & $0(0.0 \%)$ & n.a \\
\hline Seroma & $0(0.0 \%)$ & $0(0.0 \%)$ & 1.000 \\
\hline Hematoma & $1(6.6 \%)$ & $0(0.0 \%)$ & 1.000 \\
\hline Urinary Retention & $1(6.6 \%)$ & $0(0.0 \%)$ & n.a \\
\hline Inguinal Parasthesias & $0(0.0 \%)$ & $6(40.0 \%)$ & 0.0304 \\
\hline Chronic groin pain & $0(0.0 \%)$ & 8.0 & \\
\hline Total complications & 2.0 & & \\
\hline
\end{tabular}

\section{Hospital Stay}

In TAPP procedure using fibrin sealant, mean hospital stay was $21.33 \pm 5.93$ hours, ranging between 12 to 28 hours; while as in TAPP procedure using tackers, mean hospital stay was $26.53 \pm 8.60$ hours, ranging between 12 to 36 hours. It was noted that fibrin sealant group of patients had less duration of hospital stay than the tacker group of patients, but being statistically insignificant $(P$ value $=0.0641$ ) (unpaired $t$ test).

In TEP procedure using fibrin sealant, mean hospital stay was $17.86 \pm 5.52$ hours, ranging between 10 to 24 hours, while as in TEP procedure using tackers, mean hospital stay was $22.40 \pm 8.72$ hours, ranging between 10 to 36 hours. It was noted that fibrin sealant group of patients had less duration of hospital stay than the tacker group of patients, but being statistically insignificant $(P$ value $=0.0995)$ (unpaired $t$ test) .

\section{Recurrence}

In TAPP procedure, only one patient who underwent repair with tackers had recurrence during the follow-up period of 2 years. $P$ value $=$ 1.000 (fisher exact test).

In TEP procedure, only one patient who underwent repair with tackers had recurrence during the follow-up period of 2 years. $\mathrm{P}$ value = 1.000 (fisher exact test).

In our study, we found a marginal difference in the cost of the two groups, fibrin sealant and stapled tackers; with tackers costing more than double than that of $1 \mathrm{ml}$ Tisseel kit. Glue fixation costed a total of INR 7000 (including the Duplocath applicator), while stapled fixation costed INR 15,000 ; with the other expenses in both types of fixation being equal. 


\section{DISCUSSION}

Inguinal hernia repair is one of the most common elective procedures performed in General surgery. The goal of hernia repair include minimizing intraoperative and postoperative complications, achieving effective repair, lowest possible recurrence, rapid return to normal life, cost effectiveness and better cosmetic results. For these reasons, various methods of inguinal hernia repair have been utilized over the past. The technique of herniorraphy has progressed from open to various laparoscopic techniques.

During the past few years, attention has focused on the pain that may arise after groin hernia surgery. Chronic pain after hernia surgery is a complex and controversial problem that affects not only open but also laparoscopic procedures. Three pain syndromes have been identified: somatic, neuropathic, and visceral pain. Besides nerve damage during dissection, thermal injury due to electrocautery, and inflammatory and/or mechanical reaction to the mesh, stapling of the mesh is the most frequent evocated mechanism ${ }^{4}$. There is a great variation in the rate of postoperative chronic pain, ranging from $0.1 \%$ to $0.4 \%$ and $22.5 \%$ in laparoscopic repairs for which staples are used to attach the mesh ${ }^{9}$. For laparoscopic hernia repair, the possibility of nerve injury (pain or paresthesia) caused by entrapment from incorrect placement of staples (above all lateral cutaneous femoral nerve, but ilioinguinal, and genitofemoral are also at risk) and epigastric vessels injury by clips application may be avoided using fibrin glue either in the TAPP technique or in the TEP. It seems that not only entrapment but also postoperative fibrous scar around the staples can lead to nerve injury. In conventional TAPP, the prosthesis is anchored using metal clips. This is a critical step that requires the utmost attention to avoid damaging the surrounding nerves and blood vessels. Lesions arising due to such intraoperative damage can lead to complications, including hemorrhage, or painful neuralgia during follow-up. Lesions of the lateral cutaneous femoral nerve are the most frequent postoperative neurologic complications associated with laparoscopy ${ }^{10}$. Such lesions are the result of damage or entrapment of the nerve during lateral fixation of the mesh to the deep inguinal ring with pain in the lateral region of thigh. TAPP hernia repair with Tisseel resulted in a low rate of postoperative pain and rapid resumption of normal activities ${ }^{11}$.

Studies point to the fact that mesh stapling does play a key role in generating postoperative pain after laparoscopic hernia repair. Mesh fixation with fibrin glue is preferable as it meets the requirements for both efficiency and security of fixation $^{12}$.

The recurrence rate in the fibrin glue was found to be slightly lower than in the tack staples group but did not differ significantly. Inadequate lateral fixation is the main cause of recurrence after both TAPP and TEP ${ }^{13,14}$. There is a reason for this is that most of the nerves run laterally, where no staples can be applied. Gluing a large mesh on the triangles of doom and pain is likely to stop the prosthesis from lifting and dislocating, thereby avoiding inferomedial and inferolateral recurrence. It is not known if the enhanced inflammatory response induced by fibrin glue may explainthe slightly higher rate of seromas in the fibrin glue meshfixation. There exists no significant difference in the development of postoperative hematomas. Although, no comparison is available between the tack staples group and the fibrin glue group in terms of operation duration, the use of fibrin glue and its application device did not seem to change the mean operative time, which is comparable to that of other series using tackers. This can be attributed primarily to the peritoneum closure using a running laparoscopic suture and the preparation of fibrin glue and its applicator during the hernial sac dissection ${ }^{15}, 16$, and 17 . From a mechanical standpoint, fixation of the mesh was equivalent to that obtained with clips but prevented complications related to the application of staples (bleeding and hematomas in space of Retzius, neuralgia andchronic pain). 


\section{CONCLUSION}

The use of fibrin glue has a distinct advantage in laparoscopic treatment of inguinal hernias compared with other conventional methods of mesh fixation due to low risk of post- and intraoperative complications, such as bleeding, seroma, chronic pain, has a lower incidence of postoperative neuralgia and provides an early faster return to normalcy. Mesh fixation with fibrin glue is preferable as it meets the requirements for both efficiency and security of fixation.

\section{REFERENCES}

1. Vader VL, Vogt DM, Zucker KA, et al. Adhesion formation in laparoscopic inguinal hernia repair. Surg. Endosc 1997;11:825.

2. Nienhuijs SW, Boelens OB, Strobbe LJ. Pain after anterior mesh hernia repair. J Am Coll Surg. 2005;200:885-9.

3. Paajanen H. Do absorbable mesh sutures cause less chronic pain than non absorbable sutures after Lichtenstein inguinal herniorraphy? Hernia. 2002;6:117-20.

4. Pooblan AS, Bruce J, Smith WC, King PM, Krukowski $\mathrm{ZH}$, Chambers WA. A review of chronic pain after inguinal herniorraphy. Clin J Pain. 2003;19:48-54.

5. Katkhouda N. A new technique for laparoscopic hernia repair using Fibrin sealant. Surg. Technol Int. 2004;12:120-6.

6. Ten Hallers EJ, Jansen JA, Marres HA, Rakhorst G, Verkerke GJ. Histological assessment of titanium and polypropylene Fiber mesh implantation with and without fibrin tissue glue. J Biomed Mater Res A. 2007;80:372-80.

7. Lovisetto F, Zonta S, Rota E, Mazzilli M, Berdone M, Bottero L, Faillance G, Longoni M. Use of human fibrin glue(Tissucol) versus staples for mesh fixation in laparoscopic trans abdominal preperitoneal hernio plasty. Ann Surg. 2007;245:222-31.

8. Lau H. Fibrin sealant versus mechanical stapling for mesh fixation during endoscopic extraperitoneal inguinal hernioplasty. Ann Surg. 2005;242:670-75.

9. Katkhouda N; Mavor E; Friedlander M.H; et al.Use of fibrin sealant for prosthetic mesh fixation in laparoscopic extraperitoneal inguinal hernia repair. Ann Surg. 2001;233:18-25.

10. Malangoni MA, Rosen MJ. Hernias. In: Townsend CM, Beauchamp RD, Evers BM. Mattox KL, eds. Sabiston textbook of surgery. Pa: Saunders Elsevier. 2010;1155;1160-1.

11. Manthey D, Nicks BA. Hernias. e-medicine website www. e-medicine.com/emerg/topic 251.htm.

12. McIntosh A, Hutchinson A, Roberts A, et al. evidence based management of groin hernia in primary care- a systemic review. Fam Pract. 2000;17:442.

13. AmFam, Bax T, Sheppard BC, Cross RA. Surgical options in the management of groin hernias. Physician. 1999;59:143-56.

14. Wantz G. E. Abdominal wall hernias. In: Schwartz $\mathrm{SI}$, ed. Principles of surgery. $7^{\text {th }}$ ed. New York, NY: Mc Graw Hill. 1999;1585-1611.

15. Patrick J.Javid, David C. Brooks. Hernias. In :Zinner MJ, Ashley SW, eds. Maingot's Abdominal Operations. Pa: McGraw Hill; $11^{\text {th }}$ edition; Chap. 5: $104,105,116,117$.

16. Kingsnorth AN, Wright D, Porter CS, Robertson G. Prolene hernia system compared with Lichtenstein patch: a randomized double blind of short term and medium term outcomes in primary inguinal hernia repair. Hernia. 2002;6:113-9.

17. Ferzli G, Sayad P, Huie F, et al. Endoscopic extraperitonealHerniorraphy: A 5-year experience. Surg. Endosc. 1998;12:1 
Yazışma Adresi / Address for Correspondence:

Dr. Hanief Mohamed Dar,

Postgraduate department of surgery,

GMC, Srinagar, Jammu \& Kashmir,

INDIA.

E-mail: drhaniefms@gmail.com.

Geliş tarihi/Received on : 22.01.2015

Kabul tarihi/Accepted on: 24.02.2014 